\title{
PENGARUH KREDIT USAHA RAKYAT (KUR) TERHADAP PENINGKATAN PROFIT USAHA MIKRO PADA NASABAH PT. BANK BUKOPIN CABANG MEDAN SETIA BUDI
}

\author{
${ }^{1}$ Aldillah Dimas Prayogi, ${ }^{2}$ Edi Sofian, ${ }^{3}$ Faty Rahmarisa \\ ${ }_{1,2,3}^{1}$ Universitas Islam Sumatera Utara \\ Ialdillah.dimas@gmail.com, ${ }^{2}$ edisofian@fe.uisu.ac.id, ${ }^{3}$ faty.rahmarisa@fe.uisu.ac.id
}

\begin{abstract}
The formulation of the problem in this thesis is whether there is an effect of using funds to increase the profit of micro business customers of PT. Bank Bukopin Medan Setia Budi Branch, is there any effect of the amount of credit on increasing the profit of micro business customers of PT. Bank Bukopin Medan Setia Budi Branch, is there any effect of credit burden on increasing the profit of micro business customers of PT. Bank Bukopin Medan Setia Budi Branch, is there any effect of the procedure on increasing the profit of micro business customers of PT. Bank Bukopin Medan Setia Budi Branch. This study aims to determine the effect of the use of funds, the amount of credit, credit burden, and procedures to increase the profit of micro business customers of PT. Bank Bukopin Medan Setia Budi Branch. This type of research is associative research with a quantitative approach. The sample in this study amounted to 69 KUR customers from PT. Bank Bukopin Medan Setia Budi Branch. The analysis technique used is path analysis. The results of this study indicate that the use of funds has no effect on increasing the profit of micro business customers of PT. Bank Bukopin Medan Setia Budi Branch. The amount of credit has a significant positive effect on increasing the profit of micro business customers of PT. Bank Mandiri (Persero) Tbk KCP Medan Wahidin. Credit burden has a significant positive effect on increasing the profit of micro business customers of PT. Bank Bukopin Medan Setia Budi Branch. The procedure has no effect on increasing the profit of micro-business customers of PT. Bank Bukopin Medan Setia Budi Branch.
\end{abstract}

Keywords : People's Business Credit, Profit Increase, Micro Business.

ABSTRAK : Rumusan masalah dalam skripsi ini adalah apakah ada pengaruh penggunaan dana terhadap peningkatan profit usaha mikro nasabah PT. Bank Bukopin Cabang Medan Setia Budi, apakah ada pengaruh jumlah kredit terhadap peningkatan profit usaha mikro nasabah PT. Bank Bukopin Cabang Medan Setia Budi, apakah ada pengaruh beban kredit terhadap peningkatan profit usaha mikro nasabah PT. Bank Bukopin Cabang Medan Setia Budi, apakah ada pengaruh prosedur terhadap peningkatan profit usaha mikro nasabah PT. Bank Bukopin Cabang Medan Setia Budi. Penelitian ini bertujuan untuk mengetahui pengaruh penggunaan dana, jumlah kredit, beban kredit, dan prosedur terhadap peningkatan profit usaha mikro nasabah PT. Bank Bukopin Cabang Medan Setia Budi. Jenis penelitian ini adalah penelitian asosiatif dengan pendekatan kuantitatif. Sampel dalam penelitian ini berjumlah 69 orang nasabah KUR dari PT. Bank Bukopin Cabang Medan Setia Budi. Teknik analisis yang digunakan adalah analisis jalur. Hasil penelitian ini menunjukkan bahwa penggunaan dana tidak berpengaruh terhadap peningkatan profit usaha mikro nasabah PT. Bank Bukopin Cabang Medan Setia Budi. Jumlah kredit berpengaruh positif signifikan terhadap peningkatan profit usaha mikro nasabah PT. Bank Mandiri (Persero) Tbk KCP Medan Wahidin. Beban kredit berpengaruh positif signifikan terhadap peningkatan profit usaha mikro nasabah PT. Bank Bukopin Cabang Medan Setia Budi. Prosedur tidak berpengaruh terhadap peningkatan profit usaha mikro nasabah PT. Bank Bukopin Cabang Medan Setia Budi.

Kata Kunci : Kredit Usaha Rakyat, Peningkatan Profit, Usaha Mikro

\section{Pendahuluan}

Kredit memiliki peran yang strategis sebagai salah satu sumber modal yang diperlukan dalam membiayai kegiatan usaha. Fasilitas kredit yang diberikan oleh bank merupakan aset terbesar bagi setiap perbankan, oleh karena itu secara 
umum perbankan memiliki kegiatan memberikan fasilitas kredit, resiko kerugian sebagian besar bersumber pada kegiatan tersebut, sehingga bila tidak dikelola dengan baik dan disertai pengawasan yang memadai akan mengancam kelangsungan hidup bank tersebut.

Sedangkan kebijakan Kredit Usaha Rakyat (KUR) terhitung sejak tanggal 24 Agustus 2010 plafon maksimal KUR tanpa agunan dari Rp. 5 juta menjadi Rp20 juta. Hal ini diperkuat oleh pernyataan Menteri Koperasi dan Usaha Kecil Menengah (UKM) pada masa itu, Sjarifuddin Hasan mengatakan usaha mikro segera bisa mengakses kredit usaha rakyat (KUR) Rp. 20 juta, segera setelah nota kesepahaman (MoU) dengan enam bank pemerintah dan 13 bank pembangunan daerah. Bank pemerintah yang ambil bagian dalam MoU adalah Bank Mandiri, BNI, BRI, BTN, Bank Syariah Mandiri, dan Bukopin. Payung hukum dalam bentuk MoU mengubah plafon maksimal KUR tanpa agunan dari Rp. 5 juta menjadi Rp. 20 juta tanpa agunan tersebut tidak memerlukan surat keputusan 2 Menteri Keuangan (Ekon.go.id, 2018). Kementerian Koordinator (Kemenko) Bidang Perekonomian mencatat realisasi sementara penyaluran Kredit Usaha Rakyat (KUR) sepanjang tahun 2019 mencapai Rp 139,51 triliun terhadap 4,7 juta debitur. Jumlah ini setara 99,65\% dari target tahun 2019 yang ditetapkan sebesar Rp 140 triliun (Kontan.co.id, 2020).

PT. Bank Bukopin Cabang Medan merupakan salah satu bank yang menyalurkan Kredit Usaha Usaha Rakyat (KUR). PT. Bank Bukopin Cabang Medan telah menyalurkan Kredit Usaha Rakyat (KUR) sebesar Rp 2,15 triliun, dengan 25.279 debitur. Di antara usaha mikro, kecil dan menengah, usaha mikro salah satu yang memiliki peran penting dalam pembangunan ekonomi karena tingkat penyerapan tenaga kerjanya yang cukup tinggi dan kebutuhan modal investasinya yang kecil. Hal ini membuat usaha mikro tidak rentan terhadap berbagai perubahan eksternal sehingga pengembangan pada sektor usaha mikro dapat menunjang diversifikasi ekonomi dan percepatan perubahan struktural yang merupakan prasyarat bagi pembangunan ekonomi jangka panjang yang stabil dan berkesinambungan.

Terkait dengan hal tersebut, sektor usaha mikro merupakan usaha yang tangguh ditengah krisis ekonomi. Usaha mikro makin tahan banting dan tetap optimistis ditengah krisis, hal ini dibuktikan ketika badai krisis moneter melanda Indonesia pada tahun 1997-1998, usaha berskala mikro relatif mampu bertahan dibandingkan perusahaan besar. Hal ini dikarenakan mayoritas usaha berskala mikro tidak terlalu tergantung pada modal besar atau pinjaman dari luar dalam mata uang asing. Bertahannya usaha mikro dalam menghadapi krisis dan kondisi perekonomian yang tidak stabil telah menunjukkan betapa pentingnya sektor ini dalam perekonomian nasional. Pentingnya usaha mikro, khususnya di negara berkembang sering dikaitkan dengan masalah ekonomi dan sosial seperti kemiskinan, pengangguran, ketimpangan distribusi pendapatan, dan yang lainnya. Artinya, keberadaan usaha mikro diharapkan dapat memberi kontribusi positif terhadap upaya penanggulangan masalah-masalah tersebut di atas (Tambunan, 2016: 2).

Melihat besarnya peran perbankan dan usaha mikro terhadap pertumbuhan ekonomi di Indonesia, maka dengan adanya program Kredit Usaha Rakyat (KUR) pemerintah juga berharap setiap usaha mikro, kecil dan menengah dan khususnya mikro dapat meningkatkan profit atau keuntungan usahanya. Terlebih lagi permasalahan usaha mikro yang paling sering ditemui adalah modal yang terbatas. Para pelaku usaha mungkin saja memiliki banyak ide bisnis untuk mengembangkan usahanya, namun harus terhenti karena tidak adanya modal tambahan. Jika ditelusuri ke belakang, banyak pelaku usaha mikro yang kesulitan untuk mendapatkan modal tambahan dari lembaga keuangan dikarenakan banyaknya persyaratan yang belum terpenuhi.

Selain masalah permodalan, dalam hal ini pelaku usaha juga membutuhkan pinjaman dari perbankan dengan jumlah kredit yang mampu mencukupi semua kebutuhan yang diperlukan dalam mengembangkan usahanya. Selain hal tersebut, ternyata masih banyak perbankan yang menetapkan beban kredit (bunga) yang tergolong tinggi sehingga banyak usaha mikro yang enggan untuk melakukan pinjaman, sehingga dalam masalah ini dengan adanya pemberian kredit dengan bunga dan angsuran yang ringan dirasa sangat penting mengingat kebutuhan pembiayaan modal kerja dan investasi diperlukan untuk menjalankan usaha dan mengembangkan skala usahanya.

Selanjutnya para pelaku usaha mikro juga mengalami kesulitan untuk memenuhi 
persyaratan yang ditawarkan oleh pihak bank, biasanya prosedur yang harus dilalui cukup lama dengan persyaratan serta jaminan yang masih sulit untuk dipenuhi oleh pelaku usaha mikro, oleh karena itu dalam pengajuan kredit dibutuhkan prosedur yang mudah dan tidak mempersulit nasabah, sehingga semua persyaratan dapat terpenuhi, dan dengan demikian dana pinjaman yang diajukan untuk memenuhi kebutuhan modal usaha dapat segera diperoleh dan digunakan untuk menjalankan usahanya.

Kemudian dari pihak nasabah sendiri setelah memperoleh pinjaman kredit usaha seringkali melakukan kesalahan dalam penggunaan dana, oleh karena itu perlu dipastikan bahwa dana yang diperoleh pelaku usaha tersebut dimanfaatkan dengan baik dan tidak dialih fungsikan untuk keperluan konsumtif lainnya. Terkait dengan masalah ini, maka untuk memperoleh hasil yang optimal tentunya pembinaan dan pendampingan kepada pelaku usaha harus dijalankan, agar penggunaan dana yang diberikan sudah sesuai dengan yang seharusnya, yaitu meningkatkan modal kerja sehingga usaha mereka dapat berkembang dan mampu menjadi penopang perekonomian.

\subsection{Batasan Masalah}

Mengingat keterbatasan kemampuan analisis, biaya, waktu dan untuk memperjelas penelitian ini, maka penulis membatasi masalah ini tentang pengaruh Kredit Usaha Rakyat (KUR) terhadap peningkatan profit usaha mikro pada nasabah".

\subsection{Rumusan Masalah}

Berdasarkan identifikasi masalah, maka rumusan masalahnya adalah :

1. Apakah ada pengaruh penggunaan dana terhadap peningkatan profit usaha mikro nasabah PT. Bank Bukopin Cabang Medan Setia Budi?

2. Apakah ada pengaruh jumlah kredit terhadap peningkatan profit usaha mikro nasabah PT. Bank Bukopin Cabang Medan Setia Budi?

3. Apakah ada pengaruh beban kredit terhadap peningkatan profit usaha mikro nasabah PT. Bank Bukopin Cabang Medan Setia Budi?

4. Apakah ada pengaruh prosedur terhadap peningkatan profit usaha mikro nasabah PT. Bank Bukopin Cabang Medan Setia Budi ?

\subsection{Tujuan Penelitian}

Adapun tujuan dari penelitian ini adalah :
1. Untuk mengetahui pengaruh penggunaan dana terhadap peningkatan profit usaha mikro nasabah PT. Bank Bukopin Cabang Medan Setia Budi.

2. Untuk mengetahui pengaruh jumlah kredit terhadap peningkatan profit usaha mikro nasabah PT. Bank Bukopin Cabang Medan Setia Budi

3. Untuk mengetahui pengaruh beban kredit terhadap peningkatan profit usaha mikro nasabah PT. Bank Bukopin Cabang Medan Setia Budi.

4. Untuk mengetahui pengaruh prosedur terhadap peningkatan profit usaha mikro nasabah PT. Bank Bukopin Cabang Medan Setia Budi.

\subsection{Hipotesis} berikut:

Hipotesis dalam penelitian ini sebagai

H1 : Penggunaan dana secara parsial berpengaruh positif signifikan terhadap peningkatan profit usaha mikro nasabah PT. Bank Bukopin Cabang Medan Setia Budi

H2 : Jumlah kredit secara parsial berpengaruh positif signifikan terhadap peningkatan profit usaha mikro nasabah PT. Bank Bukopin Cabang Medan Setia Budi

H3 : Beban kredit secara parsial berpengaruh positif signifikan terhadap peningkatan profit usaha mikro nasabah PT. Bank Bukopin Cabang Medan .

H4 : Prosedur secara parsial berpengaruh positif signifikan terhadap peningkatan profit usaha mikro nasabah PT. Bank Bukopin Cabang Medan KCP Medan.

H5 : Penggunaan dana, jumlah kredit, beban kredit, dan prosedur secara serempak berpengaruh positif signifikan terhadap peningkatan profit usaha mikro nasabah PT. Bank Bukopin Cabang Medan .

\section{Metode Penelitian}

\subsection{Populasi}

Menurut Kuncoro (2009:188) populasi adalah kelompok elemen yang lengkap, biasanya berupa orang, objek, transaksi atau kejadian dimana kita tertarik untuk mempelajari atau menjadi objek penelitian. Adapun populasi dalam penelitian ini ialah seluruh nasabah KUR dari PT. Bank Bukopin Cabang Medan yang jumlahnya sebanyak 220 orang.

\subsection{Sampel}


Sampel adalah bagian dari jumlah dan karakteristik yang dimiliki oleh populasi tersebut. Bila populasi besar, dan peneliti tidak mungkin mempelajari semua yang ada pada populasi, misal karena keterbatasan dana, tenaga dan waktu, maka peneliti dapat menggunakan sampel yang diambil dari populasi itu. Apa yang dipelajari dari sampel, kesimpulannya akan dapat diberlakukan untuk populasi. Untuk sampel yang diambil dari populasi harus betul-betul mewakili. (Sugiyono, 2017: 91).

Teknik pengambilan sampel yang digunakan dalam penelitian ini adalah purposive sampling. Purposive sampling merupakan teknik pengambilan sampel dengan pertimbangan khusus sehingga layak dijadikan sampel. Pengambilan sampel harus sesuai dengan kriteria tersebut, karena akan berpengaruh pada variabel yang akan diteliti, jumlah populasi dalam penelitian ini adalah sebanyak 69 nasabah.

\subsection{Teknik Analisis Data}

Teknik analisis data dalam penelitian ini adalah dengan menggunakan metode analisis deskriptif yang didasarkan pada penggambaran yang mendukung analisa tersebut, analisis ini menekankan pada pemahaman mengenai masalah-masalah dalam kehidupan sosial berdasarkan kondisi realitas atau natural setting yang holistis, kompleks, dan rinci yang sifatnya menjelaskan secara uraian atau bentuk kalimat.

Analisis data merupakan bagian dari proses pengujian data yang hasilnya digunakan sebagai bukti yang memadai untuk menarik kesimpulan penelitian. Untuk mendukung hasil penelitian, data penelitian yang diperoleh akan dianalisis dengan data statistik melalui bantuan program SPSS 23. Metode analisis yang digunakan dalam penelitian ini yaitu deskriptif statistik yang berfungsi sebagai penganalisis data dengan menggambarkan sampel data yang telah dikumpulkan tanpa penggeneralisasian. Penelitian ini memberikan gambaran atau deskripsi suatu data yang dilihat dari nilai ratarata, standar deviasi, varian, maksimum, minimum, sum, dan range. (Ghozali, 2016:78)

\section{Hasil Dan Pembahasan Hasil Penelitian 3.1. Uji Validitas}

Adapun hasil uji validitas dalam penelitian ini dapat dilihat pada tabel berikut :

Tabel 1

Hasil Uji Validitas

\begin{tabular}{|c|c|c|c|}
\hline Penggunaan Dana & $\mathbf{r}_{\text {hitung }}$ & $\mathbf{r}_{\text {tabel }}$ & Keterangan \\
\hline $\begin{array}{l}\text { Saya telah menggunakan KUR dengan baik } \\
\text { sebagai sumber modal usaha }\end{array}$ & 0,525 & \multirow{5}{*}{0,361} & \multirow{5}{*}{ Valid } \\
\hline $\begin{array}{l}\text { Saya juga menggunakan KUR untuk selain } \\
\text { keperluan usaha }\end{array}$ & 0,670 & & \\
\hline $\begin{array}{l}\text { Pinjaman KUR digunakan untuk membeli bahan } \\
\text { baku guna meningkatkan } \\
\text { Produksi }\end{array}$ & 0,765 & & \\
\hline $\begin{array}{l}\text { Pinjaman KUR digunakan untuk menambah } \\
\text { variasi atau jumlah produk }\end{array}$ & 0,456 & & \\
\hline $\begin{array}{l}\text { Pinjaman KUR digunakan untuk memperluas } \\
\text { kapasitas usaha }\end{array}$ & 0,525 & & \\
\hline Jumlah Kredit & $\mathbf{r}_{\text {hitung }}$ & $\mathbf{r}_{\text {tabel }}$ & Keterangan \\
\hline $\begin{array}{l}\text { Jumlah dana yang diterima sesuai dengan yang } \\
\text { diajukan }\end{array}$ & 0,454 & \multirow{5}{*}{0,361} & \multirow{5}{*}{ Valid } \\
\hline $\begin{array}{l}\text { Jumlah dana yang diterima memenuhi kebutuhan } \\
\text { modal usaha }\end{array}$ & 0,394 & & \\
\hline $\begin{array}{l}\text { Jumlah dana pinjaman mampu meningkatkan } \\
\text { perkembangan usaha }\end{array}$ & 0,548 & & \\
\hline $\begin{array}{l}\text { Jumlah dana pinjaman dapat meningkatan volume } \\
\text { penjualan }\end{array}$ & 0,576 & & \\
\hline $\begin{array}{l}\text { Jumlah dana pinjaman mampu meningkatkan } \\
\text { pendapatan usaha }\end{array}$ & 0,499 & & \\
\hline
\end{tabular}




\begin{tabular}{|c|c|c|c|}
\hline Beban Kredit & $\mathbf{r}_{\text {hitung }}$ & $\mathbf{r}_{\text {tabel }}$ & Keterangan \\
\hline $\begin{array}{l}\text { Beban kredit sesuai dengan kesepakatan bersama } \\
\text { pihak Bank }\end{array}$ & 0,880 & \multirow{5}{*}{0,361} & \multirow{5}{*}{ Valid } \\
\hline $\begin{array}{l}\text { Beban kredit tergolong rendah dibandingkan } \\
\text { kredit usaha lainnya }\end{array}$ & 0,765 & & \\
\hline Beban kredit tidak memberatkan nasabah & 0,562 & & \\
\hline $\begin{array}{l}\text { Tingkat angsuran kredit per bulan sesuai dengan } \\
\text { kesepakatan yang ditetapkan oleh pihak Bank }\end{array}$ & 0,755 & & \\
\hline $\begin{array}{l}\text { Kredit Usaha Rakyat memberikan angsuran yang } \\
\text { cukup ringan }\end{array}$ & 0,871 & & \\
\hline Prosedur & $\mathbf{r}_{\text {hitung }}$ & $\mathbf{r}_{\text {tabel }}$ & Keterangan \\
\hline \multicolumn{2}{|l|}{$\begin{array}{lcc}\text { Pendampingan yang diberikan pada proses } \\
\text { pengajuan KUR dilaksanakan dengan baik }\end{array}$} & \multirow{5}{*}{0,361} & \multirow{5}{*}{ Valid } \\
\hline $\begin{array}{l}\text { Pemenuhan persyaratan dokumen tergolong } \\
\text { mudah }\end{array}$ & & & \\
\hline $\begin{array}{l}\text { Pemenuhan persyaratan agunan/jaminan } \\
\text { tergolong mudah }\end{array}$ & & & \\
\hline $\begin{array}{l}\text { Persyaratan jaminan yang ditetapkan tidak } \\
\text { memberatkan nasabah }\end{array}$ & & & \\
\hline $\begin{array}{llll}\begin{array}{l}\text { Biaya administrasi } \\
\text { terjangkau }\end{array} & \text { pengajuan } & \text { KUR } & \text { relatif } \\
\end{array}$ & & & \\
\hline Profit Usaha & $\mathbf{r}_{\text {hitung }}$ & $\mathbf{r}_{\text {tabel }}$ & Keterangan \\
\hline $\begin{array}{l}\text { Penghasilan usaha saya mencukupi biaya hidup } \\
\text { selama in }\end{array}$ & 0,860 & \multirow{3}{*}{0,361} & \multirow{3}{*}{ Valid } \\
\hline Saya mampu mengembangkan usaha saya & 0,834 & & \\
\hline Keuntungan yang saya peroleh lebih banyak & 0,601 & & \\
\hline
\end{tabular}

Melalui hasil uji validitas pada tabel di atas dapat dilihat bahwa seluruh pernyataan yang digunakan dalam kuesioner telah valid, sehingga seluruh data yang dikumpulkan dapat digunakan untuk menjadi bahan analisis dalam penelitian ini.

\subsection{Hasil Uji Reliabilitas}

Hasil uji reliabilitas dalam penelitian ini dapat dilihat pada tabel berikut ini.

Tabel 2

Hasil Uji Reliabilitas

\begin{tabular}{|l|r|}
\hline $\begin{array}{l}\text { Cronbach's } \\
\text { Alpha }\end{array}$ & N of Items \\
\hline .841 & 23 \\
\hline
\end{tabular}

Sumber: Hasil Pengujian SPSS 21.0 for Windows, 2021
Melalui hasil uji reliabilitas pada tabel di atas dapat dilihat bahwa nilai cronbach alpha sebesar 0,841 dari total 23 pernyataan. Sehingga dapat disimpulkan bahwa seluruh pernyataan yang digunakan pada kuesioner dalam penelitian ini telah reliabel dan memiliki tingkat reliabilitas yang sangat baik.

\subsection{Hasil Uji Asumsi Klasik}

Uji asumsi klasik dalam penelitian ini dilakukan untuk mengetahui kualitas data yang akan dianalisis. Adapun uji asumsi klasik dalam penelitian ini terdiri dari uji normalitas dengan kolmogorov-smirnov $z$, multikolinearitas, dan heteroskedastisitas dengan glejser.

1) Hasil Uji Normalitas

Hhasil uji normalitas dalam penelitian ini dapat dilihat pada tabel berikut : 
Tabel 2.

Hasil Uji Normalitas

One-Sample Kolmogorov-Smirnov Test

\begin{tabular}{|ll|r|}
\hline & & $\begin{array}{r}\text { Unstandardize } \\
\text { d Residual }\end{array}$ \\
\hline $\mathrm{N}$ & Mean & 69 \\
Normal Parameters ${ }^{\mathrm{a}, \mathrm{b}}$ & Std. &, 0000000 \\
& Deviation &, 63520121 \\
Most Extreme & Absolute &, 112 \\
Differences & Positive &, 103 \\
Kolmogorov-Smirnov Z & Negative &,- 112 \\
Asymp. Sig. (2-tailed) & &, 112 \\
a. Test distribution is Normal. &, 353 \\
b. Calculated from data. & \\
\end{tabular}

Melalui hasil uji normalitas pada tabel di atas dapat dilihat bahwa nilai Asymp.Sig. (2tailed) sebesar 0,353>0,05 sehingga dapat disimpulkan bahwa data yang digunakan dalam penelitian ini telah berdistribusi normal.
2) Hasil Uji Multikolinearitas

Adapun hasil uji multikolinearitas dalam penelitian ini dapat dilihat pada tabel berikut.

Tabel 4

Hasil Uji Multikolinearitas

Coefficients $^{\mathrm{a}}$

\begin{tabular}{|c|c|c|c|c|c|c|}
\hline \multirow{2}{*}{\multicolumn{2}{|c|}{ Model }} & \multicolumn{2}{|c|}{$\begin{array}{l}\text { Unstandardized } \\
\text { Coefficients }\end{array}$} & \multirow{2}{*}{$\begin{array}{l}\text { Standardized } \\
\text { Coefficients } \\
\text { Beta } \\
\end{array}$} & \multirow{2}{*}{$\begin{array}{c}\text { Collinearit } \\
\text { y } \\
\text { Tolerance }\end{array}$} & \multirow[t]{2}{*}{$\begin{array}{l}\text { Statistics } \\
\text { VIF }\end{array}$} \\
\hline & & B & Std. Error & & & \\
\hline \multirow{5}{*}{1} & (Constant) & 857 & 1,576 & & & \\
\hline & X1 &,- 025 & ,063 &,- 028 &, 780 & 1,283 \\
\hline & $\mathrm{X} 2$ &, 175 & ,064 & ,271 & ,709 & 1,410 \\
\hline & X3 & ,381 & ,072 & ,581 & ,585 & 1,711 \\
\hline & X4 & ,026 & ,073 & ,037 & ,654 & 1,529 \\
\hline
\end{tabular}

Melalui hasil uji multikolinearitas pada tabel diatas dapat dilihat bahwa penggunaan dana memiliki nilai tolerance sebesar $0,780>0,1$ dengan nilai VIF sebesar $1,283<10$. Jumlah kredit memiliki nilai tolerance sebesar 0,709 > 0,1 dengan nilai VIF sebesar 1,410 < 10. Beban kredit memiliki nilai tolerance sebesar $0,585>$ 0,1 dengan nilai VIF sebesar $1,711<10$. Prosedur memiliki nilai tolerance sebesar 0,654
$>0,1$ dengan nilai VIF sebesar $1,529<10$. Sehingga dapat disimpulkan bahwa tidak terdapat gejala multikolinearitas pada data yang digunakan dalam penelitian ini.

3) Hasil Uji Heteroskedastisitas

Adapun hasil uji heteroskedastisitas dalam penelitian ini dapat dilihat pada Tabel berikut. 
Tabel 5.Hasil Uji Heteroskedastisitas

Coefficients $^{\mathrm{a}}$

\begin{tabular}{|c|c|c|c|c|c|c|}
\hline \multirow{2}{*}{\multicolumn{2}{|c|}{ Model }} & \multicolumn{2}{|c|}{$\begin{array}{l}\text { Unstandardized } \\
\text { Coefficients }\end{array}$} & \multirow{2}{*}{$\begin{array}{c}\text { Standardized } \\
\text { Coefficients } \\
\text { Beta }\end{array}$} & \multirow[t]{2}{*}{$\mathrm{t}$} & \multirow[t]{2}{*}{ Sig. } \\
\hline & & B & Std. Error & & & \\
\hline \multirow{5}{*}{1} & (Constant) & ,308 & 1,094 & &,- 190 & , 850 \\
\hline & $\mathrm{X} 1$ &,- 001 &, 044 &,- 005 &,- 033 & ,974 \\
\hline & $\mathrm{X} 2$ & , 028 & , 044 & , 092 & 629 & ,532 \\
\hline & $\mathrm{X} 3$ & 051 &, 050 & , 166 & 1,029 & ,307 \\
\hline & X4 &,- 045 & ,051 &,- 136 &,- 896 & ,374 \\
\hline
\end{tabular}

Melalui hasil uji multikolinearitas pada tabel di atas dapat dilihat bahwa penggunaan dana memiliki nilai sig sebesar 0,974 >0,05. Jumlah kredit memiliki nilai sig sebesar 0,532 >0,05. Beban kredit memiliki nilai sig sebesar 0,307 > 0,05 . Prosedur memiliki nilai sig sebesar 0,374 $>0,05$ sehingga dapat disimpulkan bahwa tidak terdapat gejala heteroskedastisitas pada data yang digunakan dalam penelitian ini.

\subsection{Hasil Analisis Jalur}

Sebelum melakukan analisis jalur, yang perlu dilakukan adalah menghitung standar error. Standar error dihitung dengan rumus 1 $\mathrm{R}$ Square. Adapun nilai $\mathrm{R}$ Square dalam penelitian ini adalah 0,556, maka e $=1-0,556$ dan $\mathrm{e}=0,444$. Adapun hasil analisis jalur dalam penelitian ini dapat dilihat pada tabel berikut.

Tabel 6 Hasil Analisis Jalur

Coefficients $^{\mathrm{a}}$

\begin{tabular}{|c|c|c|c|c|c|c|c|}
\hline \multirow[t]{2}{*}{ Model } & \multicolumn{2}{|c|}{$\begin{array}{l}\text { Unstandardized } \\
\text { Coefficients }\end{array}$} & \multirow{2}{*}{$\begin{array}{c}\begin{array}{c}\text { Standardize } \\
\mathrm{d}\end{array} \\
\text { Coefficients }\end{array}$} & \multirow[t]{2}{*}{$\mathrm{t}$} & \multirow[t]{2}{*}{ Sig. } & \multirow{2}{*}{$\begin{array}{c}\text { Collinearit } \\
\text { y } \\
\text { Tolerance }\end{array}$} & \multirow[t]{2}{*}{$\begin{array}{l}\text { Statistics } \\
\text { VIF }\end{array}$} \\
\hline & B & $\begin{array}{l}\text { Std. } \\
\text { Error }\end{array}$ & & & & & \\
\hline $\begin{array}{l}\text { (Constan } \\
\text { t) }\end{array}$ & 857 & 1,576 & & ,544 & ,589 & & \\
\hline $\mathrm{X} 1$ &,- 025 & 063 &,- 038 &,- 405 & 687 & ,780 & 1,283 \\
\hline${ }^{1} \quad \mathrm{X} 2$ & ,175 & ,064 & ,271 & 2,734 & ,008 & ,709 & 1,410 \\
\hline X3 & ,381 & ,072 & ,581 & 5,328 & ,000 & ,585 & 1,711 \\
\hline $\mathrm{X} 4$ & ,026 & ,073 & 037, & ,357 & ,722 & ,654 & 1,529 \\
\hline
\end{tabular}

Berdasarkan hasil analisis jalur pada tabel diatas dapat dibuat persamaan sebagai berikut:

$\mathrm{Y}=-, 038 \mathrm{PYX}_{1}+0,271 \mathrm{PYX}_{2}+0,581$

$\mathrm{PYX}_{3}+0,037 \mathrm{PYX}_{4}+0,444 e$
Melalui persamaan analisis jalur tersebut, maka dapat digambarkan model jalur sebagai berikut:

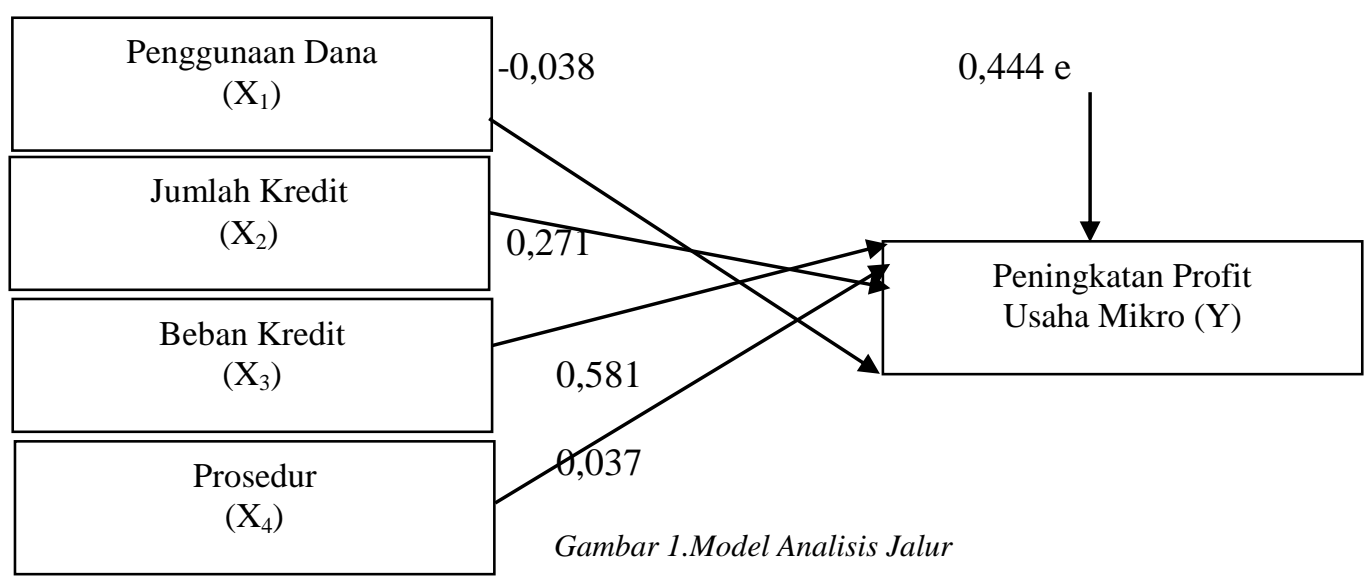


Berdasarkan gambar persamaan tersebut, maka dapat diuraikan penjelasan sebagai berikut:

1. Jika penggunaan dana turun sebesar 1 (satuan), maka nilai peningkatan profit usaha akan turun sebesar -,038.

2. Jika jumlah kredit sebesar 1 (satuan), maka nilai peningkatan profit usaha akan naik sebesar 0,271.

3. Jika beban kredit sebesar 1 (satuan), maka nilai peningkatan profit usaha akan naik sebesar 0,581 .

4. Jika prosedur sebesar 1 (satuan), maka nilai peningkatan profit usaha akan naik sebesar 0,037 .
5. Apabila nilai penggunaan dana, jumlah kredit, beban kredit, dan prosedur terus meningkat, maka nilai peningkatan profit usaha akan naik menjadi menjadi 0,444.

\subsection{Hasil Uji Hipotesis}

Uji hipotesis dalam penelitian ini dilakukan untuk membuktikan kebenaran hipotesis dalam penelitian ini. Adapun uji hipotesis dalam penelitian ini terdiri dari uji signifikansi parsial (uji-t), uji signifikansi simultan (uji-F), dan koefisien determinasi (R2).

1) Hasil Uji Signifikansi Parsial (Uji-t)

Adapun hasil uji signifikansi parsial (uji-t) dalam penelitian ini dapat dilihat pada tabel berikut :

Tabel 7

Hasil Uji Signifikansi Parsial (Uji-t)

Coefficients $^{\mathrm{a}}$

\begin{tabular}{|c|c|c|c|c|c|c|c|}
\hline \multirow[t]{2}{*}{ Model } & \multicolumn{2}{|c|}{$\begin{array}{l}\text { Unstandardized } \\
\text { Coefficients }\end{array}$} & \multirow{2}{*}{$\begin{array}{c}\begin{array}{c}\text { Standardize } \\
\mathrm{d} \\
\text { Coefficients }\end{array} \\
\text { Beta }\end{array}$} & \multirow[t]{2}{*}{$\mathrm{t}$} & \multirow[t]{2}{*}{ Sig. } & \multirow{2}{*}{$\begin{array}{c}\text { Collinearit } \\
y \\
\text { Tolerance }\end{array}$} & \multirow[t]{2}{*}{$\begin{array}{l}\text { Statistics } \\
\text { VIF }\end{array}$} \\
\hline & B & $\begin{array}{l}\text { Std. } \\
\text { Error }\end{array}$ & & & & & \\
\hline $\begin{array}{l}\text { (Constan } \\
\text { t) }\end{array}$ & 857 & 1,576 & & ,544 & ,589 & & \\
\hline $\mathrm{X} 1$ &,- 025 & 063 &,- 038 &,- 405 & 687, & ,780 & 1,283 \\
\hline${ }^{1} \mathrm{X} 2$ &, 175 & ,064 & ,271 & 2,734 & ,008 & ,709 & 1,410 \\
\hline X3 & ,381 & ,072 & ,581 & 5,328 & ,000 & ,585 & 1,711 \\
\hline $\mathrm{X} 4$ & ,026 & ,073 & ,037 & ,357 & ,722 & ,654 & 1,529 \\
\hline
\end{tabular}

a. Dependent Variable: Y

Melalui hasil uji signifikansi parsial (uji-t) pada tabel diatas dapat dilihat bahwa penggunaan dana memiliki nilai thitung sebesar $-0,405<$ ttabel $-1,669$ dengan sig sebesar 0,687 $>0,05$ sehingga dapat disimpulkan bahwa penggunaan dana tidak berpengaruh terhadap peningkatan profit usaha dalam penelitian ini. Jumlah kredit memiliki nilai thitung sebesar $2,734>$ ttabel 1,669 dengan sig sebesar 0,008< 0,05 sehingga dapat disimpulkan bahwa jumlah kredit berpengaruh signifikan terhadap peningkatan profit usaha dalam penelitian ini. Beban kredit memiliki nilai thitung sebesar $5,328>$ ttabel 1,669 dengan sig sebesar 0,000 <
0,05 sehingga dapat disimpulkan bahwa beban kredit berpengaruh signifikan terhadap peningkatan profit usaha dalam penelitian ini. Prosedur memiliki nilai thitung sebesar 0,357 < ttabel 1,669 dengan sig sebesar 0,722 >0,05 sehingga dapat disimpulkan bahwa prosedur tidak berpengaruh terhadap peningkatan profit usaha dalam penelitian ini.

2) Hasil Uji Signifikansi Simultan (Uji-F)

Adapun hasil uji signifikansi simultan (ujiF) dalam penelitian ini dapat dilihat pada tabel berikut : 
Tabel 8

Hasil Uji Signifikansi Simultan (Uji-F) ANOVA $^{\mathrm{a}}$

\begin{tabular}{|c|c|c|c|c|c|c|}
\hline \multicolumn{2}{|c|}{ Model } & $\begin{array}{l}\text { Sum of } \\
\text { Squares }\end{array}$ & $\overline{\mathrm{df}}$ & Mean Square & $\bar{F}$ & Sig. \\
\hline \multirow{3}{*}{1} & Regression & 34,302 & 4 & $\overline{8,576}$ & 20,004 &, $000^{b}$ \\
\hline & Residual & 27,437 & 64 & , 429 & & \\
\hline & Total & 61,739 & 68 & & & \\
\hline
\end{tabular}

a. Dependent Variable: $Y$

b. Predictors: (Constant), X4, X1, X3, X2

Melalui hasil uji signifikansi simultan (uji-F) pada Tabel 4.17 dapat dilihat bahwa nilai Fhitung sebesar 20,004 > Ftabel 2,36 dengan sig sebesar $0,000<0,05$ sehingga dapat disimpulkan bahwa secara serempak penggunaan dana, jumlah kredit, beban kredit, dan prosedur berpengaruh psoitif signifikan terhadap peningkatan profit usaha.

\section{3) Hasil Koefisien Determinasi (R2)}

Adapun hasil koefisien determinasi (R2) dalam penelitian ini dapat dilihat pada tabel berikut :

Tabel 9.

Hasil Koefisien Determinasi (R2) Model Summary ${ }^{\mathrm{b}}$

\begin{tabular}{|l|r|r|r|r|}
\hline Model & $\mathrm{R}$ & $\mathrm{R}$ Square & $\begin{array}{c}\text { Adjusted R } \\
\text { Square }\end{array}$ & $\begin{array}{c}\text { Std. Error of } \\
\text { the Estimate }\end{array}$ \\
\hline 1 &, $540^{\mathrm{a}}$ &, 291 &, 247 & 1,175 \\
\hline
\end{tabular}
a. Predictors: (Constant), $X 4, X 1, X 3, X 2$
b. Dependent Variable: $Y$

Melalui hasil koefisien determinasi (R2) pada tabel diatas dapat dilihat bahwa nilai $R$ Square sebesar 0,556. Nilai tersebut memberikan arti bahwa dalam penelitian ini penggunaan dana, jumlah kredit, beban kredit, dan prosedur memiliki kontribusi atau mampu menjelaskan peningkatan profit usaha sebesar $55,6 \%$ sedangkan sisanya sebesar $44,4 \%$ dijelaskan oleh variabel lain diluar penelitian ini.

\section{Evaluasi}

4.1.Pengaruh Penggunaan Dana KUR terhadap Peningkatan Profit Usaha Mikro Nasabah PT. Bank Bukopin Cabang Medan Setia Budi

Berdasarkan hasil penelitian ini diketahui bahwa penggunaan dana KUR tidak berpengaruh terhadap peningkatan profit usaha mikro nasabah PT. Bank Bukopin Cabang Medan Setia Budi. Hal ini disimpulkan berdasarkan hasil uji signifikansi parsial (uji-t) yang diperoleh nilai thitung sebesar $-0,405<$ ttabel - 1,669 dengan sig sebesar 0,687>0,05.

Hal ini membuktikan bahwa penggunaan dana KUR saja tidak menjadi acuan atau jaminan bagi pengusaha untuk dapat meningkatkan profit usaha mereka. Penggunaan dana yang tidak tepat, seperti digunakan untuk hal lain yang diluar keperluan usaha tidak akan memberikan dampak apapun terhadap usaha yang dijalankannya. Pada kenyataannya juga masih banyak pengusaha yang melakukan hal seperti ini, saat mereka menerima dana KUR, mereka menggunakan dana tersebut untuk keperluan lain diluar keperluan usaha mereka, seperti membeli perhiasan, kendaraan, barang rumah tangga, dan lain sebagainya.

Hasil penelitian ini juga sejalan dengan penelitian yang dilakukan oleh Atin (2018) dengan judul penelitian "Pengaruh Efektivitas Kredit Usaha Rakyat (KUR) Terhadap Peningkatan Profit Usaha Mikro (Studi Kasus Pada Nasabah Bank Rakyat Indonesia Unit Purwomartani Kalasan Sleman Yogyakarta)" yang menyatakan bahwa penggunaan dana tidak berpengaruh terhadap peningkatan profit usaha.

\subsection{Pengaruh Jumlah Kredit KUR terhadap Peningkatan Profit Usaha Mikro Nasabah PT. Bank Bukopin Cabang Medan Setia Budi.}


Berdasarkan hasil penelitian ini diketahui bahwa jumlah kredit KUR berpengaruh positif signifikan terhadap peningkatan profit usaha mikro nasabah PT. Bank Bukopin Cabang Medan Setia Budi. Hal ini disimpulkan berdasarkan hasil uji signifikansi parsial (uji-t) yang diperoleh nilai $t_{\text {hitung }}$ sebesar 2,734 $>$ ttabel 1,669 dengan sig sebesar 0,008 <0,05. Hal ini membuktikan bahwa dengan jumlah kredit KUR yang besar atau tepat dan sesuai dengan kebutuhan pelaku usaha mikro, maka dapat memberikan dampak terhadap peningkatan profit usaha mereka. Apabila jumlah kredit KUR yang didapatkan besar, maka pelaku usaha dapat menggunakannya sebagai tambahan modal, membeli keperluan atau alatalat yang mampu mendukung produktivitas usaha mereka, dan lain sebagainya. Meningkatnya produktivitas usaha, maka akan meningkatkan profit usaha tersebut.

Hasil penelitian ini juga sejalan dengan penelitian yang dilakukan oleh Atin (2018) dengan judul penelitian "Pengaruh Efektivitas Kredit Usaha Rakyat (KUR) Terhadap Peningkatan Profit Usaha Mikro (Studi Kasus Pada Nasabah Bank Rakyat Indonesia Unit Purwomartani Kalasan Sleman Yogyakarta)" yang menyatakan bahwa jumlah kredit berpengaruh terhadap peningkatan profit usaha.

\subsection{Pengaruh Beban Kredit KUR terhadap Peningkatan Profit Usaha Mikro Nasabah PT. Bank Bukopin Cabang Medan Setia Budi}

Berdasarkan hasil penelitian ini diketahui bahwa beban kredit KUR berpengaruh positif signifikan terhadap peningkatan profit usaha mikro nasabah PT. Bank Bukopin Cabang Medan Setia Budi. Hal ini disimpulkan berdasarkan hasil uji signifikansi parsial (uji-t) yang diperoleh nilai thitung sebesar 5,328 $>$ ttabel 1,669 dengan sig sebesar $0,000<0,05$. Hal ini membuktikan bahwa beban kredit KUR Bank Bukopin Cabang Medan Setia Budi yang ringan mampu meningkatkan profit usaha nasabah. Ringannya beban kredit KUR yang diberikan menjadi salah satu poin penting yang memberikan dampak positif terhadap profit usaha mikro, karena dengan beban kredit yang ringan, pelaku usaha dapat membayarkan angsuran kreditnya dengan nominal yang jauh lebih kecil dibandingkan dengan KUR dari bank lain, sehingga pelaku usaha dapat memperoleh profit yang lebih tinggi dari hasil usahanya.
Hasil penelitian ini juga sejalan dengan penelitian yang dilakukan oleh Atin (2018) dengan judul penelitian "Pengaruh Efektivitas Kredit Usaha Rakyat (KUR) Terhadap Peningkatan Profit Usaha Mikro (Studi Kasus Pada Nasabah Bank Rakyat Indonesia Unit Purwomartani Kalasan Sleman Yogyakarta)" yang menyatakan bahwa beban kredit berpengaruh terhadap peningkatan profit usaha.

\subsection{Pengaruh Prosedur Kredit KUR terhadap Peningkatan Profit Usaha Mikro Nasabah PT. Bank Bukopin Cabang Medan Setia Budi}

Berdasarkan hasil penelitian ini diketahui bahwa prosedur kredit KUR tidak berpengaruh terhadap peningkatan profit usaha mikro nasabah PT. Bank Bukopin Cabang Medan Setia Budi. Hal ini disimpulkan berdasarkan hasil uji signifikansi parsial (uji-t) yang diperoleh nilai thitung sebesar $0,357<\mathrm{t}_{\text {tabel }}$ 1,669 dengan sig sebesar 0,722>0,05. Hal ini membuktikan bahwa prosedur tidak memberikan dampak apapun terhadap peningkatan profit pelaku usaha mikro nasabah Bank Bukopin Cabang Medan Setia Budi. Mudah atau sulitnya prosedur yang diberikan oleh bank tidak akan menjadi pengaruh utama dalam peningkatan profit pelaku usaha, karena prosedur hanya sebuah urutan atau aturan yang disesuaikan oleh pihak bank dalam pengajuan kredit KUR, sementara semua prosedur tersebut belum menjadi jaminan bahwa pengajuan nasabah KUR diterima atau tidaknya, sehingga apabila semua prosedur telah terpenuhi sekalipun, tetap saja nasabah harus menunggu persetujuan dari pihak bank untuk menerima dana KUR.

Hasil penelitian ini juga sejalan dengan penelitian yang dilakukan oleh Atin (2018) dengan judul penelitian "Pengaruh Efektivitas Kredit Usaha Rakyat (KUR) Terhadap Peningkatan Profit Usaha Mikro (Studi Kasus Pada Nasabah Bank Rakyat Indonesia Unit Purwomartani Kalasan Sleman Yogyakarta)" yang menyatakan bahwa prosedur tidak berpengaruh terhadap peningkatan profit usaha

\section{Kesimpulan}

Sesuai hasil analisis penelitian maka dapat diambil kesimpulan sesuai tujuan penelitian yang dikemukakan.

1) Penggunaan dana tidak berpengaruh terhadap peningkatan profit usaha mikro 
nasabah PT. Bank Bukopin Cabang Medan Setia Budi.

2) Jumlah kredit berpengaruh positif signifikan terhadap peningkatan profit usaha mikro nasabah PT. Bank Bukopin Cabang Medan Setia Budi

3) Beban kredit berpengaruh positif signifikan terhadap peningkatan profit usaha mikro nasabah PT. Bank Bukopin Cabang Medan Setia Budi

4) Prosedur tidak berpengaruh terhadap peningkatan profit usaha mikro nasabah PT. Bank Bukopin Cabang Medan Setia Budi.

\section{DAFTAR PUSTAKA}

Agus Tri Basuki, N. P. (2016). Analisis Regresi Dalam Penelitian Ekonomi \& Bisnis : Dilengkapi Aplikasi SPSS \& EVIEWS. Jakarta: PT. Rajagrafindo Persada.

Atin, T. D. N. (2018). Pengaruh Efektivitas Kredit Usaha Rakyat (KUR) Terhadap Peningkatan Profit Usaha Mikro (Studi Kasus Pada Nasabah Bank Rakyat Indonesia Unit Purwomartani Kalasan Sleman Yogyakarta). Universitas Negeri Yogyakarta.

Ghozali, I. (2016). Aplikasi Analisis Multivariate dengan Program IBM SPSS 23. Semarang: BPFE Universitas Diponegoro.

Hanafi, M. (2015). Manajemen Keuangan (Cetakan Ke). Yogyakarta: BPFE Universitas Diponegoro.

Harahap, S. S. (2015). Teori Akuntansi. Jakarta: Rajawali Press.

Hasibuan, H. M. S. (2017). Dasar-Dasar Perbankan. Jakarta: PT. Bumi Aksara.

Ismail. (2015). Manajemen Perbankan. Jakarta: Kencana.

Kasmir. (2014). Dasar-Dasar Perbankan. Jakarta: PT. Rajagrafindo Persada.

---------(2016). Analisis Laporan Keuangan. Jakarta: PT. Rajagrafindo Persada.

Kuncoro, M. (2014). Metode Riset untuk Bisnis \& Ekonomi (Edisi Keti). Jakarta: Erlangga.

Lastina, N. L. M. A. D. (2018). Efektivitas Penyaluran Kredit Usaha Rakyat PT. BRI (Persero) Unit Blahkiuh Terhadap Produktivitas Ukm Dan Pendapatan 